\title{
Analisis SOAR Dalam Strategi Pelayanan Pasca Diklat Penguatan Kepala Sekolah di BPSDM Provinsi DKI Jakarta
}

\author{
'Sopan Adrianto, ${ }^{2}$ Agus Kurniati \\ 'BPSDM Provinsi DKI Jakarta \\ 2Pendidikan dan Pelatihan Badan Siber dan Sandi Negara \\ email: agus.kurniati@bssn.go.id
}

\begin{abstract}
Abstrak
Dalam menyelenggarakan Diklat PKS, BPSDM Provinsi DKI Jakarta dituntut untuk menghasilkan lulusan yang mampu menyusun dokumen RPS dalam rangka peningkatan mutu pendidikan. Permasalahan yang dihadapi adalah banyaknya lulusan diklat yang mengalami kesulitan pada saat penyusunan dokumen RPS serta perlu adanya bimbingan sehingga dokumen yang RPS dihasilkan dapat diterapkan dengan baik dalam rangka peningkatan mutu pendidikan. Salah satu langkah strategis yang dapat ditempuh adalah melalui pelayanan pasca diklat. Tujuan dari penelitian ini adalah menganalisis strategi pengembangan pasca Diklat PKS menggunakan analisis strategi SOAR. Metode penelitian yang digunakan adalah deskriptif kualitatif. Pengumpulan data dilakukan melalui wawancara, observasi dan kuesioner. Data yang diperoleh kemudian diolah dan ditabulasi sebagai dasar dalam melakukan analisis SOAR. Analisis yang digunakan adalah analisis SOAR dengan melakukan perhitungan matriks IFAS-EFAS. Berdasarkan hasil analisis SOAR, BPSDM DKI Jakarta berada kuadran strategi III yaitu strategi OA yakni memanfaatkan peluang yang ada untuk mencapai hasil yang diharapkan dengan cara membuat wadah/media dalam rangka mengoptimalkan dan memelihara kompetensi lulusan Diklat PKS sebagai bentuk layanan pasca diklat PKS melalui pembuatan ruang konsultasi manajeraial kepala sekolah
\end{abstract}

Keywords: Diklat PKS, analisis SOAR, matriks IFAS-EFAS

\begin{abstract}
The graduates of Strengthening of School Principal training were expected to be able to compile School Development Plant document which is used as a guide to improving education quality. But in reality, most of graduates have not been able to compile this document comprehensively. One of the strategic step taken to solve this problem is through post training services. This study is aimed to analyze the post training strategy of Strengthening School Principal Training using SOAR strategy analysis. The research method used is descriptive quantitative. Data collection was carried out through interview, observation and questionnaire. The data obtained were processed and tabulated for conducting SOAR analysis to calculate IFAS-EFAS matrix. Based on the result of the SOAR analysis, BPSDM Province DKI Jakarta is in the quadrant III/OA strategy quadrant. This means that BPSDM Province DKI Jakarta can take the advantages of existing opportunities to achieve the expected result by creting a platform/media to optimize and maintain the graduates competencies throught the School Principal Managerial Consultation Room.
\end{abstract}

Keywords: Strengthening School Principal Training, SOAR analysis, IFAS-EFAS matrix 


\section{PENDAHULUAN}

Untuk menghasilkan mutu pendidikan yang berkualitas, saat ini sekolah/madrasah harus berhadapan dengan tuntutan dan tantangan baru dunia pendidikan. Era globalisasi membawa dampak perubahan dalam dunia pendidikan yang sangat signifikan. Pondasi dan standar mutu yang baik sangat diperlukan dalam menyelenggarakan proses pendidikan. Terdapat 8 Standar Nasional Pendidikan yang berlaku di seluruh wilayah hukum Negara Kesatuan Republik Indonesia (NKRI) terdiri atas standar, yaitu: (1) Standar Isi, (2) Standar Proses, (3) Standar Kompetensi Lulusan, (4) Standar Pendidik dan Tenaga Kependidikan, (5) Standar Sarana dan Prasarana, (6) Standar Pengelolaan, (7) Standar Pembiayaan, dan (8) Standar Penilaian Pendidikan (Peraturan Pemerintah Nomor 32 Tahun 2013). Dalam setiap standar yang ditentukan terdapat kriterianya masing-masing. Dengan adanya penerapan standar tersebut, setiap Kepala Sekolah dituntut untuk dapat menyusun, melaksanakan, serta memonitor dan mengevaluasi Rencana Pengembangan Sekolah (RPS) guna memenuhi standar tersebut dan selanjutnya berusaha meningkatkan kualitasnya ke standar yang lebih tinggi. Kepala Sekolah menjadi kunci utama dan tokoh sentral untuk mewujudkan perbaikan kinerja manajemen sekolah dan peningkatan kualitas pendidikan.

Dokumen RPS menggambarkan arah perjalanan perubahan sekolah dari suatu kondisi sekarang menuju kondisi yang lebih baik dan lebih menjanjikan dalam kurun waktu baik untuk jangka panjang (20 tahun), menengah (5 tahun) maupun pendek (1 tahun) ke depan. Berdasarkan hasil penelitian yang berjudul Efektifitas Model Pembelajaran Kooperatif Tipe STAD Berbasis Keterampilan 4C pada Pendidikan dan Pelatihan Penguatan Kepala Sekolah (Diklat PKS) Angkatan 20 di BPSDM Provinsi DKI Jakarta diketahui bahwa 66,7\% dari peserta Diklat PKS menyatakan belum dan kurang mampu dalam menyusun RPS. (Dr. Sopan Adrianto, S.E, M.Pd, 2019).

Untuk memperkuat data tersebut, Penulis yang merupakan pengajar Diklat PKS melakukan wawancara secara langsung terhadap para peserta Diklat PKS. Wawancara dilakukan pada ketua tim kelompok belajar dengan harapan bahwa ketua tim kelompok belajar akan mewakili anggota timnya. Berdasarkan hasil wawancaran yang dilakukan terhadap para Kepala Sekolah yang mengikuti Diklat PKS, hampir sebagian besar menyatakan bahwa mereka masih memerlukan bimbingan dan pendampingan dalam menyusun dokumen RPS, mengingat pentingnya fungsi RPS sebagai dokumen panduan dalam menyelenggarakan pendidikan. Dari hasil wawancara juga diperoleh informasi mengenai faktor kendala dalam penyusunan dokumen RPS. Faktor penyebabnya antara lain adalah: (1) Beberapa kepala sekolah masih kesulitan dalam menyusun dokumen RPS serta ringkasannya. Sampai saat ini sebagian kepala sekolah masih lebih memfokuskan perhatiannya pada pembangunan fisik sekolah. (2) Sebagian besar kepala sekolah tidak membentuk kelompok kerja yang bertugas untuk mengembangkan dan merumuskan tujuan dan hasil yang ingin dicapai sekolah dalam jangka pendek, menengah, dan jangka panjang. (3) Rendahnya kompetensi manajerial kepala sekolah. (4) Masih kurangnya peran dan fungsi pengawas sekolah dalam melakukan bimbingan dan pembinaan bagi kepala sekolah terkait dengan administrasi dan dokumen RPS.

Berdasarkan Neraca Pendidikan Provinsi DKI Jakarta dijabarkan tentang laporan dari Uji Kompetensi Kepala Sekolah (UKKS) di DKI Jakarta yang dilaksanakan pada tahun 2015, diperoleh hasil sebagai berikut (Direktorat Peningkatan Mutu Pendidik dan Tenaga Kependidikan, 2016):

a. Nilai rata-rata nasional adalah 56,37 ;

b. Nilai rata-rata perdimensi UKKS sebagai berikut, kepemimpinan pembelajaran : 43,96; kewirausahaan : 58,75; manajerial : 58,55; supervisi : 51,81 ; dan usaha pengembangan sekolah : 47,67.

c. Nilai rata-rata untuk perjenjang adalah: kepala SMA 60,89; kepala SMK : 60,52; kepala SMP : 60,17 dan kepala SD : 56,80.

Secara umum dari data yang diperoleh UKKS Tahun 2015 mengindikasikan bahwa nilai ratarata pada semua aspek sesuai kriteria penggolongannya masih relatif rendah, data 
ini mengindikasikan masih diperlukan upaya yang berkelanjutan dalam rangka peningkatan kompetensi kepala sekolah yang rata-rata masih kurang agar seluruh kepala sekolah mempunyai penguasaan kompetensi yang mencukupi.

Untuk menjawab tantangan di atas, BPSDM Provinsi DKI Jakarta menyelenggarakan Diklat Penguatan Kepala Sekolah (PKS) untuk para kepala sekolah dan calon kepala sekolah berbagai jenjang di wilayah Provinsi DKI Jakarta. Sampai dengan tahun 2019, BPSDM Provinsi DKI Jakarta telah menyelenggarakan sebanyak 20 angkatan. Pada akhir pelaksanaa Diklat PKS ini, peserta diklat diharuskan menyusun RPS berdasarkan 8 Standar Nasional pendidikan (SNP). Penyusunan RPS ini merupakan akumulasi dari keseluruhan materi yang didapatkan dalam Diklat PKS. Nilai penyusunan RPS merupakan salah satu indikator keberhasilan dalam Diklat PKS, ketika peserta Diklat PKS sudah menguasai materi lain dengan baik, maka akan tergambar dari RPS yang disusunnya di akhir Diklat PKS. Dokumen RPS merupakan salah satu wujud dari fungsi manajemen sekolah yang harus dimiliki oleh sekolah untuk dijadikan sebagai panduan dalam menyelenggarakan pendidikan, baik untuk jangka panjang (20 tahun), menengah (5 tahun) maupun pendek (1 tahun).

Dari hasil penilaian Lembar Kerja RPS pada pelaksanaan Diklat PKS, rata-rata masih di bawah standar kelulusan, nilai rata rata berkisar di bawah 60, yang mengindikasikan belum memenuhi Standar Kriteria Ketuntasan Minimal (SKKM). Idealnya setiap satuan pendidikan memiliki dan mengimplementasikan RPS sebagai arah dan bimbingan bagi para pelaku sekolah dalam rangka pencapaian tujuan sekolah yang lebih baik. Untuk itu masih diperlukan kegiatan pembimbingan dan pengawasan pasca dilaksanakannya diklat PKS, khususnya dalam rangka penyusunan dokumen RPS, agar dokumen yang dihasilkan berkualitas sehingga dapat meningkatkan mutu pendidikan pada setiap satuan pendidikan para almuni Diklat PKS.

Melihat data tersebut di atas, penting dilakukan analisis pengembangan agar dapat dirumuskan strategi yang tepat dan relevan dengan kondisi saat ini. Penelitian ini bertujuan untuk menentukan strategi dalam pelaksanaan Diklat PKS, agar Diklat PKS dapat terselenggara dengan baik dan mencapai output yang sesuai, yakni menghasilkan lulusan Diklat yang dapat menyusun dokumen RPS sebagai penduan dalam menjalankan proses pendidikan di sekolah. Karena kompleksnya permasalahan yang dihadapi dalam penyelenggaraan kegiatan Diklat PKS, maka penelitian ini dibatasi pada penentuan strategi pada kegiatan pelayanan pasca Diklat. Diharapkan dengan diperolehnya strategi pelayanan pasca Diklat yang tepat, akan dapat dilakukan pembinaan yang baik terhadap para alumni Diklat PKS dalam menerapkan pengetahuan yang diperoleh setelah melaksanakan Diklat.

Proses penentuan strategi akan dilaksanakan dengan menggunakan analisis SOAR (Strengths, Opportunities, Aspirations, Results). Pemilihan strategi SOAR atas pertimbangan bahwa dalam strategi ini tidak melibatkan faktor kekurangan dan ancaman, karena faktor kekurangan dan ancaman akan menimbulkan perasaan negatif bagi anggota organisasi, yang berakibat dapat menurunkan motivasi untuk melakukan yang terbaik. Keunggulan lain dari stretegi ini adalah sebanyak mungkin melibatkan stakeholder.

\section{KAJIAN LITERATUR}

Konsep strategi SOAR (Strengths, Opportunities, Aspirations, Results) permaka kali dikenalkan oleh Starvos dan Kelly pada tahun 2003 sebagai alternatif terhadap analisis SWOT. SOAR merupakan strategi bisnis yang didasarkan pada hal positif yang dimiliki oleh suatu perusahaan untuk dikembangakan dan dijadikan nilai keunggulan (Starvos dan Cole, 2013). Kerangka strategi SOAR bersifat dinamis, modern dan inovatif untuk menghasilkan pemikiran strategis, menilai kinerja individu dan tim, membangun strategi serta membuat rencana strategis. Tujuan adanya SOAR dikembangkan adalah untuk mengukur kapasitas individu dalam memikirikan strategi tentang empat elemen yang berfungsi dalam dinamika orientasi masa depan pada abad ke 21. Sebagai sebuah kerangka kerja, SOAR berfokus pada perumusan dan implementasi strategi positif dengan mengidentifikasi 
kekuatan, membangun kreativitas dalam bentuk peluang, mendorong individu dan tim untuk berbagi aspirasi dan menentukan hasil yang berarti. Strategi SOAR merupakan pengembangan dari strategi SWOT dalam hal faktor-faktor kekurangan (weakness) internal organisasi serta ancaman (threats) eksternal yang dihadapinya ke dalam faktor-faktor aspirasi (aspiration) yang dimiliki perusahaan serta hasil (results) terukur yang ingin dicapai. Dalam model strategi SWOT beberapa faktor kekurangan dan ancaman dapat memunculkan perasaan negatif bagi para anggota organisasi, sehingga menurunkan motivasi mereka untuk berbuat yang terbaik (Starvos dan Cole, 2013).

Dalam kerangka kerja SOAR, melibatkan stakeholder sebanyak mungkin, yang didasarkan pada integritas para anggotanya. Integritas menjadi hal yang sangat penting karena para stakeholder harus menyadari asumsi-asumsi yang menjadi dasar penggerak bagi organisasi. Organisasi melakukan pendekatan baru yang memungkinkan untuk mencapai hasil yang lebih baik dibandingkan dengan model lain, karena mengandalkan sikap positif dan kekuatan, serta peluang dan cita-cita/harapan (Starvos dan Cole, 2013).

Beberapa penelitian terkait yang pernah dilakukan sebelumnya antara lain:

a. Penelitian yang dilakukan oleh Adelia Alfama Z (2020) dengan judul "Analisis SOAR pada Strategi Pemasaran di Industri Jasa Finance". Hasil dari penelitian ini adalah dengan menggunakan strategi SOAR dapat diketahui bahwa perusahaan mempunyai banyak potensi positif yang menjadi kekuatan dan peluang usaha baik dari internal maupun eksternal, sehingga dapat menjadi masukan dan acuan bagi perusahaan dalam menentukan strategi penjualan pada masa yang akan datang.

b. Penelitian yang dilakukan oleh Afnan Fuadi (2020) dengan judul "Analisis Strategi SOAR Balai Diklat Aparatur KKP menuju Corporate University". Hasil dari penelitian ini adalah dengan menggunakan strategi SOAR dapat dipetakan keberadaan organisasi Balai Diklta Aparatur KKP berada di kuadran strategi SA yakni dengan memanfaatkan peluang yang dimiliki organisasi untuk mencapai hasil yang diharapkan.
Dari dua penelitian di atas dapat disimpulkan bahwa strategi SOAR merupakan pilihan yang tepat untuk menentukan strategi yang akan diambil oleh suatu organisasi dengan memanfaatkan sumber daya yang ada untuk mencapai hasil yang diharapkan.

Dalam metode SOAR memiliki (empat kunci pokok yaitu : (1) menentukan aset dan kekuatan yang dimiliki oleh organisasi, (2) menentukan peluang terbaik yang dimiliki orang organisasi (3) menentukan tujuan yang ingin dicapai (4) menentukan pencapaian hasil yang terukur. Dalam penelitian ini Analisis SOAR ini digunakan untuk menentukan beberapa strategi yang ada di BPSDM Provinsi DKI Jakarta untuk mengidentifikasi kekuatan, peluang dan harapan dalam rangka peningkatan mutu penyelenggaraan Diklat PKS khususnya dalam kegiatan pelayanan pasca diklat.

Berikut merupakan kerangka berpikir dalam penelitian ini:

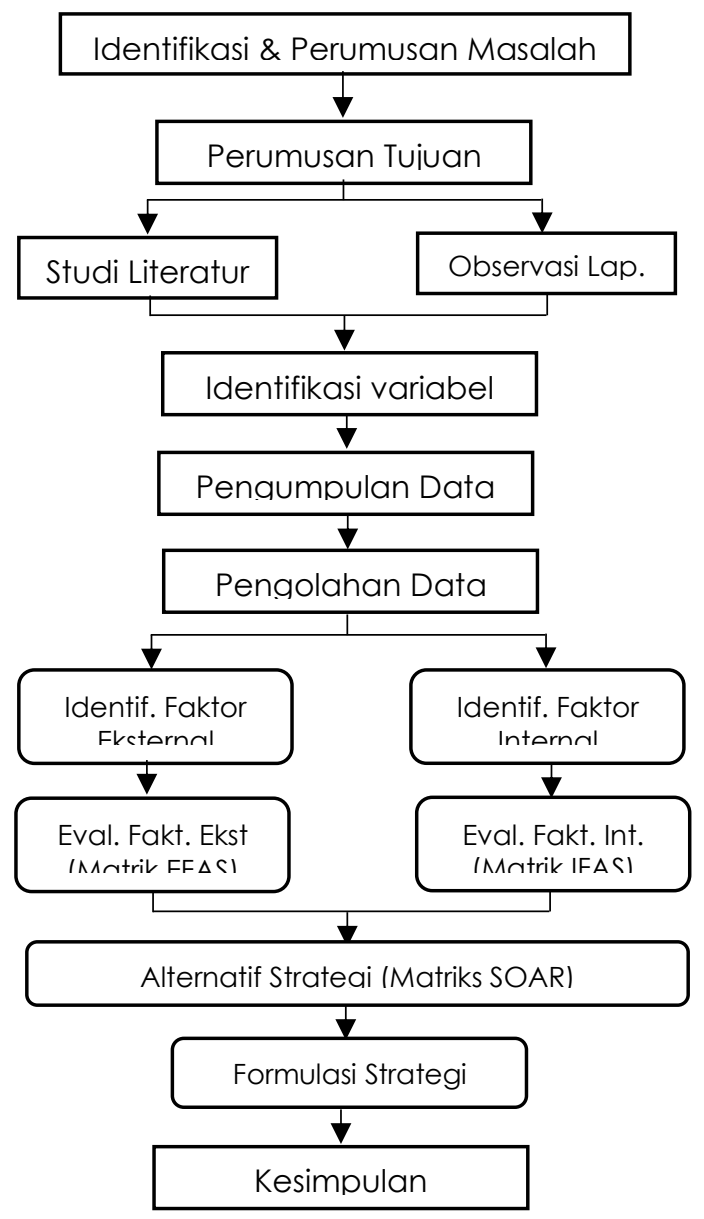

Gambar 1. Kerangka Berpikir 


\section{METODOLOGI}

Penelitian ini merupakan jenis penelitian deskriptif kuantitatif yaitu penelitian yang digunakan untuk menganalisis data dengan cara mendeskripsikan atau menggambarkan data yang telah terkumpul sebagaimana adanya. Penelitian deskriptif kuantitatif bertujuan untuk menjelaskan suatu fenomena angka yang menggambarkan karateristik

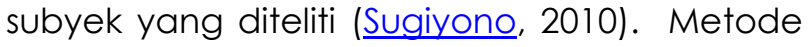
yang digunakan adalah observasi untuk memecahkan masalah yang ada menggunakan teknik analisis SOAR. Teknik pengumpulan data dilakukan melalui wawancara, observasi dan kuesioner. Kuesioner bersifat tertutup merupakan kuesioner yang sudah disediakan jawabannya, sehingga responden tinggal memilih (Arikunto, 2010). Kuesioner disebarkan kepada penyelenggara Diklat PKS. Tujuan dari penyebaran kuesioner ini adalah untuk menggali data dalam menilai setiap indikator dalam matriks SOAR. Dalam menentukan jawabanya, Penulis menggunakan skala Likert. Skala Likert digunakan untuk mengukur sikap, pendapat dan persepsi terhadap fenomena sosial (Sugiyono, 2010). Narasumber wawancara terdiri dari penyelenggara pelatihan di BPSDM Provinsi DKI Jakarta sebanyak 5 orang dan alumni peserta Diklat PKS angkatan ke-18 sebanyak 5 orang yang merupakan ketua tim/kelompok pada saat pelaksanaan Diklat PKS, sehingga diharapkan dapat mewakili aspirasi dari semua anggotanya. Observasi dilakukan selama diklat PKS berlangsung yaitu tanggal 9-19 September 2019. Penulis mengamati seluruh proses pembelajaran dan dinamika yang terjadi selama pelaksanaan pembelajaran di kelas, kemudian mencatat poin-poin penting yang menjadi target observasi.

Langkah awal dalam membuat analisa mengenai keadaan serta mengambil keputusan, dimana tahap pengumpulan data ini menggunakan wawancara dengan personil penyelenggara Diklat PKS sehingga membentuk masing-masing variabel dalam strategi SOAR. Narasumber wawancara sebanyak 5 orang yang merupakan penyelengara Diklat PKS dan 5 orang alumni Diklat PKS. Dari hasil wawancara tersebut, diperoleh hasil/keputusan bersama untuk memenuhi variabel strategi SOAR. Setiap personil diberikan kebebasan untuk berpendapat, dan dari hasil beberapa pendapat tersebut akan disimpulkan oleh peneliti menjadi suatu variabel dalam strategi SOAR. Variabel-variabel yang dihasilkan tersebut kemudian akan diolah lebih lanjut. Pengolahan data dilakukan dengan dengan metode analisis SOAR untuk mendapatkan strategi pelayanan Pasca Diklat PKS. Analisis data dilakukan melalui langkah-langkah sebagai berikut (Suhendra et al., 2020):

a. Merumuskan dan mengidentifikasi persoalan strategi yang ada sehingga jelas tujuan yang akan dipahami.

Dalam hal ini, Penulis mengidentifikasi permasalahan yang dihadapi dalam penyelenggaraan Diklat PKS, sehingga akan didapatkan akar permasalahannya.

b. Menyiapkan instrumen (antara lain: berkas, data dan sebagainya) yang diperlukan pada tahap persiapan.

Penulis menyiapkan pedoman observasi, lembar kuesioner dan pedoman wawancara.

c. Mencari data untuk pemecahan masalah yang dibutuhkan dengan pengamatan langsung, dan mendapatkan data yang lalu, wawancara dan kuesioner.

Penulis melakukan observasi pada pelaksanaan Diklat PKS, melakukan wawancara dengan penyelenggara dan alumni Diklat PKS dan menyebarkan kuesioner.

d. Melakukan pengolahan data dengan data yang sudah dikumpulkan.

Data yang telah diperoleh diolah dan dianalisis menggunakan instrumen pada startegi SOAR.

e. Melakukan metode analisis SOAR dengan menggunakan matriks SOAR yang meliputi identifikasi faktor internal, identifikasi faktor eksternal, pembuatan matrik QSPM (Quantitativ Strategic Planning Matrix).

Penulis melakukan perhitungan matriks untuk mendapatkan strategi yang tepat untuk diterapkan,

f. Memetakan strategi.

Dari hasil analisis SOAR didapatkan strategi yang tepat dalam mengembangkan program pasca diklat PKS. 


\section{HASIL DAN PEMBAHASAN Temuan}

Setelah data yang cukup melalui wawancara dengan penyelenggara dan alumni Diklat PKS, maka langkah selanjutnya adalah melakukan analisis kekuatan (strength), peluang (opportunity), harapan (aspiration) dan hasil (result). Analisis masalah dilakukan dengan menggunakan analisis SOAR. Penulis menggunakan SOAR Framework sebagai bahan pertanyaan dalam wawancara dan kuesioner yang menghasilkan jawaban untuk mendapatkan gambaran kondisi nyata dalam pelaksanaan Diklat PKS. Kegiatan ini melibatkan semua unsur penyelenggara dan stake holder Diklat PKS dalam hal ini diwakili oleh peserta Diklat PKS. Berikut merupakan langkah-langkah dalam SOAR Framework (Stavros, 2003).

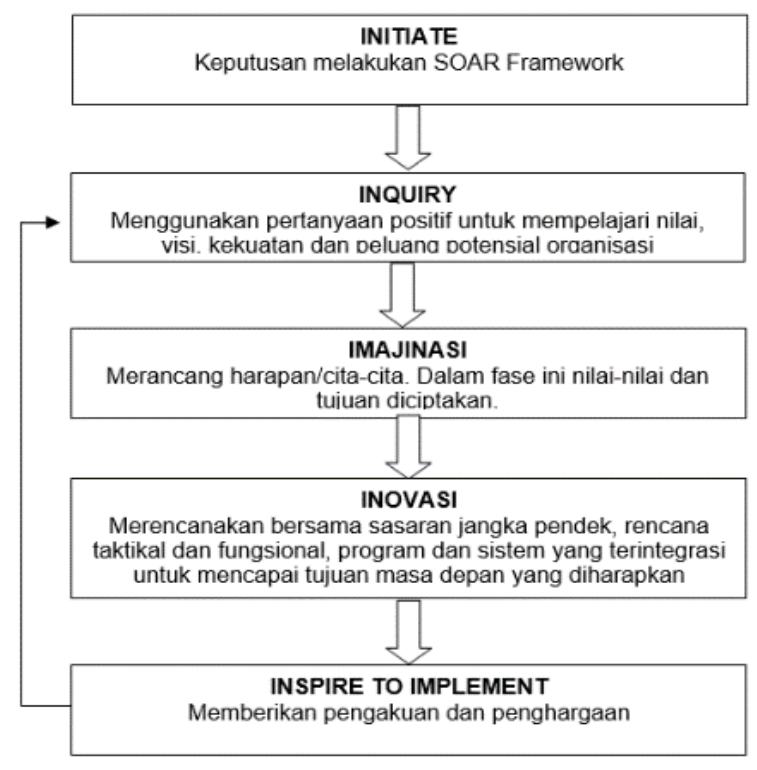

Gambar 2. SOAR Framework

Tahap pertama dalam melakukan analisis SOAR yaitu dimulai dengan tahap inisiasi (initiate) yaitu keputusan untuk memilih SOAR, kemudian dilanjutkan dengan penyelidikan (inquiry) yang menggunakan pertanyaan positif guna mempelajari nilai-nilai visi, kekuatan dan peluang potensial di lingkungan BPSDM DKI Jakarta. Pada Tahap ini setiap pendapat dari setiap anggota organisasi dihargai. Penulis juga melakukan wawancara untuk memahami secara utuh nilai-nilai organisasi serta hal-hal terbaik yang pernah terjadi di masa lalu, kemudian dibawa masuk ke dalam Tahap imajinasi, memanfaatkan waktu untuk merancang harapan. Dalam Tahap ini, nilai-nilai diperkuat dan tujuan diciptakan. Sasaran yang bersifat jangka panjang dan pilihan strategis dan rekomendasi diumumkan. Tahap selanjutnya adalah inovasi, yaitu dimulainya perancangan sasaran jangka pendek, rencana taktikal dan fungsional, program dan sistem yang terintegrasi untuk mencapai tujuan masa depan yang diharapkan untuk tercapainya hasil terbaik yang terukur, setiap orang yang terlibat diberikan inspirasi melalui sistem pengakuan dan penghargaan. Strategi SOAR sangat tepat untuk diterapkan dalam menentukan strategi pasca Diklat PKS di BPSDM Provinsi DKI Jakarta, karena melalui strategi ini dapat ditentukan faktor terbaik dan segala kekuatan yang dimiiki oleh BPSDM Provinsi DKI Jakarta. Kemudian dari faktor kelebihan yang dimiliki, dapat dicari peluang yang tersedia, aspirasi dari seluruh anggota organisasi akan diakomodir untuk menentukan hasil yang terukur. Diharapkan melalui analisis strategi SOAR ini, akan menghasilkan strategi yang terbaik dalam pelayanan pasca pelatihan Diklat PKS. Hal ini juga merupakan salah satu metode untuk memberikan pelayanan pasca diklat yang tepat.

\section{Pembahasan}

Pembuatan strategi dilaksanakan berdasarkan analisis yang diperoleh dari penerapan SOAR Framework melalui beberapa tahap antara lain:

a. Membuat matriks internal-eksternal

Matriks internal-eksternal ini dibuat pada saat melakukan pemetaan dengan menggunakan SOAR Framework.

b. Memberikan bobot pada masing-masing faktor

c. Menghitung rating dan score masingmasing faktor

d. Menyusun faktor-faktor tersebut dalam kolom 1

e. Memberi pembobotan masing-masing faktor

f. Menghitung rate (untuk masing-masing faktor mulai dari 4 (outstanding) sampai dengan 1 (poor) berdasarkan pengaruh faktor tersebut terhadap kondisi organisasi 
g. Melakukan perkalian antara bobot dengan rating untuk memperoleh faktor pembobotan

h. Menjumlahkan skor pembobotan untuk memperoleh total skor.

Rumus pembobotan variabel adalah:

(1)

$$
A i=\frac{X i}{\sum_{i=1}^{i} X i}
$$

$$
\begin{aligned}
& A_{i}=\text { jumlah variabel ke-i } \\
& n=\text { jumlah variabel } \\
& i \quad=1,2,3 \ldots n \\
& x_{i}=\text { nilai variabel ke-i }
\end{aligned}
$$

Terkait dengan pengembangan pasca pelatihan Diklat PKS, berdasarkan hasil perumusan bersama dengan anggota organisasi di BPSDM Provinsi DKI Jakarta dengan menggunakan SOAR Framework, diperoleh beberapa hasil antara lain: penentuan aset terbesar dan kekuatan-kekuatan yang dimiliki organisasi, peluang terbaik yang dimiliki organisasi, tujuan yang ingin dicapai, dan pencapaian hasil yang terukur. Berdasarkan hasil wawancara, dapat diidentifikasi beberapa strategi yang ada di BPSDM Provinsi DKI Jakarta untuk mengidentifikasi kekuatan, peluang dan harapan dalam rangka peningkatan mutu penyelenggaraan Diklat PKS. Penentuan ini tidak hanya melibatkan penyelenggara diklat, namun juga dilakukan wawancara dan penyebaran kuesioner kepada alumni peserta Diklat PKS, sehingga dari jawaban yang mereka berikan dapat membantu dalam penentuan variabel, khususnya pada variabel hasil sehingga penyelenggara diklat memperolah masukan mengenai harapan apa yang diinginkan oleh para peserta Diklat PKS. Pada tabel 1 disajikan

\begin{tabular}{|c|c|c|}
\hline & Kekuatan/Strength (S) & Kekuatan/Strength (S) \\
\hline \multirow{9}{*}{$\begin{array}{l}\text { I } \\
\text { n } \\
t \\
\text { e } \\
r \\
n \\
a \\
\text { l }\end{array}$} & a. Jumlah tenaga kediklatan yang memadai & a. Adanya regulasi yang kuat: \\
\hline & b. Sarana dan prasarana diklat yang & 1) Permendiknas no. 32 tahun 2013 \\
\hline & memadai & Permendiknas no 13 Tahun 2007 \\
\hline & c. Tersedianya dukungan DIPA & Permendikbud no. 6 Tahun 2018 \\
\hline & d. Komitmen pimpinan yang cukup tinggi & 4) PP no. 19 tahun 2017 \\
\hline & & b. Peluang kerja sama dengan lembaga \\
\hline & & penyelenggara diklat lain \\
\hline & & c. Banyaknya jumlah Kepala Sekolah dari \\
\hline & & $\begin{array}{l}\text { berbagai jenjang yang berpeluang untuk } \\
\text { mengikuti Diklat PKS } \\
\text { d. Kebijakan pemerintah yang mendukung } \\
\text { penyelenggaraan Diklat PKS }\end{array}$ \\
\hline \multirow{7}{*}{$\begin{array}{l}\text { E } \\
\text { k } \\
s \\
\text { t } \\
\text { e } \\
r \\
n \\
a \\
\text { l }\end{array}$} & $\begin{array}{l}\text { a. Menjadi lembaga penyelenggaran Diklat } \\
\text { PKS yang terpercaya }\end{array}$ & $\begin{array}{l}\text { a. Meningkatnya kepercayaan dan kepuasan } \\
\text { stake holder }\end{array}$ \\
\hline & b. Seluruh pengajar Diklat PKS mempunyai & b. Tercapainya kompetensi kepala sekolah \\
\hline & kompetensi yang cukup sesuai kriteria & melalvi Diklat PKS \\
\hline & $\begin{array}{l}\text { standar yang ditetapkan } \\
\text { c. Pembaharuan sistem pembelajaran Diklat }\end{array}$ & $\begin{array}{l}\text { c. Meningkatnya mutu pendidikan pada } \\
\text { semua jenjang di wilayah DKI Jakarta }\end{array}$ \\
\hline & PKS & d. Terjalinnya kerja sama yang baik dengan \\
\hline & $\begin{array}{l}\text { d. Tersedianya media untuk menyelesaikan } \\
\text { masalah sekolah secara kolaboratif, } \\
\text { reflektif dan berbasis data yang mampu } \\
\text { menggerakkan ekosistem pendidikan } \\
\text { menjadi lebih berdaya guna }\end{array}$ & semua pihak yang terkait \\
\hline & Harapan/Aspirations (O) & Hasil/Results (R) \\
\hline
\end{tabular}
faktor-faktor yang menjadi fokus utama dalam strategi penyelenggaraan Diklat PKS menggunakan analisis SOAR.

\section{Tabel 1. Matriks SOAR}


Setelah didapatkan faktor eksternal dan internal, selanjutnya menentukan pertanyataan kuesioner, penulis merumuskan penyataan kuesioner ini dengan cara melakukan diskusi dengan pegawai di BPSDM DKI Jakarta khususnya yang bertugas untuk menyelenggarakan Diklat PKS. Dari tahap ini dihasilkan masing-masing 4 variabel pada masing-masing komponen. Berikut hasil penentuan pernyataan kuesioner faktor internal dan eksternal dalam pelaksanaan Diklat PKS:

Tabel 2. Pernyataan Kuesioner Faktor Internal

\begin{tabular}{|c|c|c|c|}
\hline No & Kekuatan/Strength & No & Peluang/Opportunities \\
\hline S1 & $\begin{array}{l}\text { Jumlah tenaga kediklatan yang } \\
\text { memadai }\end{array}$ & $\mathrm{Ol}$ & $\begin{array}{l}\text { Adanya regulasi yang kuat: } \\
\text { a. Permendiknas no. } 32 \text { Tahun } 2013 \\
\text { b. Permendikbud no. } 6 \text { Tahun } 2018 \\
\text { c. PP no. } 19 \text { Tahun } 2017\end{array}$ \\
\hline S2 & $\begin{array}{l}\text { Sarana dan prasarana diklat yang } \\
\text { memadai }\end{array}$ & $\mathrm{O} 2$ & $\begin{array}{l}\text { Pelvang kerja sama dengan lembaga } \\
\text { penyelenggara diklat lain }\end{array}$ \\
\hline S3 & Tersedianya dukungan DIPA & O3 & $\begin{array}{l}\text { Banyaknya jumlah Kepala Sekolah yang } \\
\text { berpeluang untuk mengikuti Diklat PKS }\end{array}$ \\
\hline S4 & $\begin{array}{l}\text { Komitmen pimpinan yang cukup } \\
\text { tinggi }\end{array}$ & O4 & $\begin{array}{l}\text { Kebijakan pemerintah yang mendukung } \\
\text { Penyelenggaraan Diklat PKS }\end{array}$ \\
\hline
\end{tabular}

Tabel 3. Pernyataan Kuesioner Faktor Eksternal

\begin{tabular}{|c|c|c|c|}
\hline No & Harapan/Aspirations & No & Hasil/Results \\
\hline Al & $\begin{array}{l}\text { Menjadi lembaga penyelenggaran } \\
\text { Diklat PKS yang terpercaya }\end{array}$ & R1 & $\begin{array}{l}\text { Meningkatnya kepercayaan dan kepuasan } \\
\text { stake holder }\end{array}$ \\
\hline A2 & $\begin{array}{l}\text { Seluruh pengajar Diklat } \text { PKS } \\
\text { mempunyai kompetensi yang cukup } \\
\text { sesuai kriteria standar yang } \\
\text { ditetapkan }\end{array}$ & R2 & $\begin{array}{l}\text { Tercapainya kompetensi kepala sekolah } \\
\text { melalui Diklat PKS }\end{array}$ \\
\hline A3 & $\begin{array}{l}\text { Pembaharuan sistem pembelajaran } \\
\text { Diklat PKS }\end{array}$ & R3 & $\begin{array}{l}\text { Meningkatnya mutu pendidikan pada } \\
\text { semua jenjang di wilayah DKI Jakarta }\end{array}$ \\
\hline A4 & $\begin{array}{l}\text { Tersedianya media untuk } \\
\text { menyelesaikan masalah sekolah } \\
\text { secara kolaboratif, reflektif dan } \\
\text { berbasis data yang mampu } \\
\text { menggerakkan ekosistem pendidikan } \\
\text { menjadi lebih berdaya }\end{array}$ & R4 & $\begin{array}{l}\text { Terjalinnya kerja sama yang baik dengan } \\
\text { semua pihak yang terkait }\end{array}$ \\
\hline
\end{tabular}

Setelah dilakukan pemetaan faktor internal dan faktor eksternal organisasi, kemudian Penulis menyebarkan kuesioner untuk memperoleh nilai persepsi terhadap faktor internal dan faktor eksternal. Kuesioner disebarkan kepada 5 orang penyelenggara Diklat PKS. Kuesioner 
berupa pertanyaan tertutup dengan jawaban berupa skor angka dari 1 sampai dengan 4 untuk menggali data terhadap penilaian pada amsing-masing indikator. Dalam menentukan jawabanya, Penulis menggunakan skala Likert. Skala Likert digunakan untuk mengukur sikap, pendapat dan persepsi terhadap fenomena sosial (Sugiyono, 2010). Berdasarkan hasil kuesioner didapatkan persepsi terhadap penilaian indikator-indikator utama, yang terbagi ke dalam 2 bagian, yaitu: faktor internal dan faktor eksternal. Berdasarkan hasil penilaian faktor-faktor internal dan eksternal, selanjutnya dilakukan identifikasi unsur-unsur yang dikategorikan sebagai kekuatan, harapan, peluang dan hasil. Analisis ini didasarkan pada logika yang dapat memaksimalkan kekuatan dan peluang untuk mencapai hasil yang diharapkan. Pada tahap ini, hasil penilaian kondisi internal dan eksternal ini akan menghasilkan sebuah kelompok- kelompok faktor yaitu: kekuatan, harapan, peluang dan hasil. Kemudian dari kelompok faktor yang diperoleh tersebut akan dilakukan sebuah analisis yaitu analisis matriks SOAR, dengan melakukan interaksi penggabungan dari kelompok faktor internal matrik internal factor analysis strategy/IFAS (kekuatan, peluang), dengan kelompok faktor eksternal matrik external factor analysis strategy/EFAS (harapan, hasil).

Berikut disajikan olah data hasil kuesioner untuk Matriks IFAS dan Matriks EFAS berdasarkan rumus di atas:

Tabel 4. Matriks IFAS

\begin{tabular}{|c|c|c|c|c|}
\hline Kekuatan/Strength (S) & $\begin{array}{c}\text { Data } \\
\text { Kuesioner }\end{array}$ & Bobot & Rating & Skor \\
\hline Jumlah tenaga kediklatan yang memadai & 16 & 0,11 & 3 & 0,33 \\
\hline Sarana dan prasarana diklat yang memadai & 16 & 0,11 & 3 & 0,33 \\
\hline Tersedianya dukungan DIPA & 17 & 0,12 & 3 & 0,36 \\
\hline \multirow[t]{2}{*}{ Komitmen pimpinan yang cukup tinggi } & 16 & 0,11 & 3 & 0,33 \\
\hline & 65 & 0,45 & & 1,35 \\
\hline Peluang/Opportunities (O) & $\begin{array}{c}\text { Data } \\
\text { Kuesioner }\end{array}$ & Bobot & Rating & Skor \\
\hline $\begin{array}{l}\text { Adanya regulasi yang kuat: } \\
\text { a. Permendiknas no. } 32 \text { Tahun } 2013 \\
\text { b. Permendikbud no. } 6 \text { Tahun } 2018 \\
\text { c. PP no. } 19 \text { Tahun } 2017\end{array}$ & 19 & 0,14 & 4 & 0,56 \\
\hline $\begin{array}{l}\text { Peluang kerja sama dengan lembaga } \\
\text { penyelenggara diklat lain }\end{array}$ & 19 & 0,14 & 4 & 0,56 \\
\hline $\begin{array}{l}\text { Banyaknya jumlah Kepala Sekolah yang } \\
\text { berpeluang untuk mengikuti Diklat PKS }\end{array}$ & 18 & 0,13 & 4 & 0,52 \\
\hline \multirow[t]{2}{*}{$\begin{array}{l}\text { Kebijakan pemerintah yang mendukung } \\
\text { Penyelenggaraan Diklat PKS }\end{array}$} & 17 & 0,12 & 3 & 0,36 \\
\hline & 73 & 0,53 & & 2 \\
\hline Total & 138 & 0,98 & & 3,73 \\
\hline
\end{tabular}


Tabel 5. Matriks EFAS

\begin{tabular}{|c|c|c|c|c|}
\hline Harapan/Aspirations (A) & $\begin{array}{l}\text { Data } \\
\text { Kuesioner }\end{array}$ & Bobot & Rating & Skor \\
\hline $\begin{array}{l}\text { Menjadi lembaga penyelenggaran Diklat PKS yang } \\
\text { terpercaya }\end{array}$ & 18 & 0,13 & 4 & 0,52 \\
\hline $\begin{array}{l}\text { Seluruh pengajar Diklat PKS mempunyai kompetensi } \\
\text { yang cukup sesuai kriteria standar yang ditetapkan }\end{array}$ & 18 & 0,13 & 4 & 0,52 \\
\hline Pembaharuan sistem pembelajaran Diklat PKS & 19 & 0,14 & 4 & 0,56 \\
\hline \multirow{2}{*}{$\begin{array}{l}\text { Tersedianya media untuk menyelesaikan masalah } \\
\text { sekolah secara kolaboratif, reflektif dan berbasis } \\
\text { data yang mampu menggerakkan ekosistem } \\
\text { pendidikan menjadi lebih berdaya }\end{array}$} & 18 & 0,13 & 4 & 0,52 \\
\hline & 73 & 0,53 & & 2,12 \\
\hline Hasil/Results (R) & $\begin{array}{l}\text { Data } \\
\text { Kuesioner }\end{array}$ & Bobot & Rating & Skor \\
\hline $\begin{array}{l}\text { Meningkatnya kepercayaan dan kepuasan stake } \\
\text { holder }\end{array}$ & 16 & 0,11 & 3 & 0,33 \\
\hline $\begin{array}{l}\text { Banyaknya pengajar dari lembaga diklat lain yang } \\
\text { memiliki kualifikasi untuk mengajar diklat PKS }\end{array}$ & 16 & 0,11 & 3 & 0,33 \\
\hline $\begin{array}{l}\text { Meningkatnya mutu pendidikan pada semua } \\
\text { jenjang di wilayah DKI Jakarta }\end{array}$ & 16 & 0,11 & 3 & 0,33 \\
\hline \multirow{2}{*}{$\begin{array}{l}\text { Terjalinnya kerja sama yang baik dengan semua } \\
\text { pihak yang terkait }\end{array}$} & 17 & 0,12 & 3 & 0,36 \\
\hline & 65 & 0,45 & & 1,35 \\
\hline Total & 138 & 0,98 & & 3,47 \\
\hline
\end{tabular}

Berdasarkan Tabel matriks IFAS dan EFAS diperoleh data sebagai berikut: Total skor kekuatan/strength $\quad: 1,35$

Total skor peluang/opportunities : : 2

Total skor harapan/aspirations $\quad: 2,12$

Total skor hasil/results $\quad: 1,35$

Berdasarkan total skor di atas, maka penentuan posisi BPSDM Provinsi DKI Jakarta dapat digambarkan dalam matriks IFAS dan EFAS berikut:

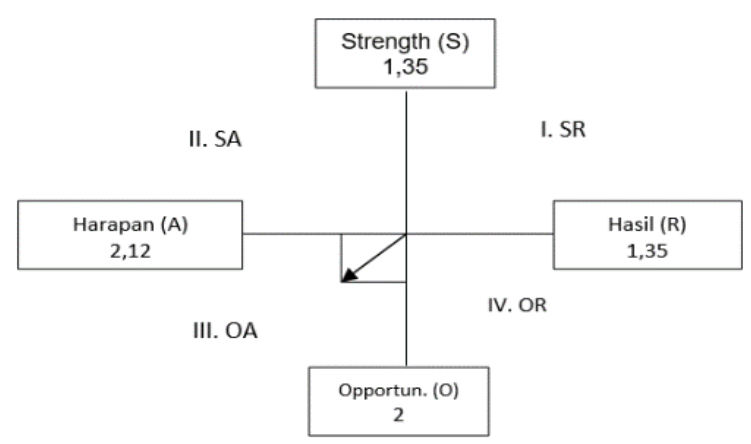

Gambar 3. Posisi Matriks SOAR
Nilai total dari matrik IFAS dan matrik EFAS digambarkan pada diagram analisis SOAR serta rumus kombinasi matrik SOAR, setelah didapatkan hasil rumusan kombinasi alternatif strategi SA, OA, SR, dan OR dari lingkungan internal dan eksternal pada tabel di atas. Rumusan alternatif strategi merupakan suatu alternatif yang digunakan oleh BPSDM Provinsi DKI Jakarta untuk menjalankan kegiatan pelatihan kedepannya. Setelah berhasil menentukan masing-masing komponen dari Strength, Opportunities, Aspirations dan Results, langkah berikutnya adalah menentukan strategi. Dalam tabel Strategi SOAR, strategi terbagi atas empat kategori yaitu :

a. Strategi SA, merupakan strategi yang memanfaatkan seluruh kekuatan untuk mencapai aspirasi yang diharapkan.

b. Strategi OA, merupakan strategi yang dibuat untuk mengetahui dan memenuhi aspirasi dari setiap stake holder yang berorientasi pada peluang yang ada. 
C. Strategi SR, merupakan strategi yang dibuat untuk mewujudkan kekuatan untuk mencapai hasil yang terukur.

Tabel 6. Kombinasi Strategi Matriks SOAR

\begin{tabular}{|c|c|c|}
\hline EFAS & $\begin{array}{l}\text { Kekuatan/Strength (S) } \\
\text { a. Jumlah tenaga kediklatan } \\
\text { yang memadai } \\
\text { b. Sarana dan prasarana diklat } \\
\text { yang memadai } \\
\text { c. Tersedianya dukungan DIPA } \\
\text { d. Komitmen pimpinan yang } \\
\text { cukup tinggi }\end{array}$ & $\begin{array}{l}\text { Peluang/Opportunities (O) } \\
\text { a.Adanya regulasi yang kuat: } \\
\text { 1)Permendiknas no. } 32 \text { tahun } \\
2013 \\
\text { 2)Permendiknas no } 13 \text { Tahun } \\
2007 \\
\text { 3)Permendikbud no. } 6 \text { Tahun } \\
2018 \\
\text { 4)PP no. } 19 \text { tahun } 2017 \\
\text { b.Peluang kerja sama dengan } \\
\text { lembaga penyelenggara diklat } \\
\text { lain } \\
\text { c. Banyaknya jumlah Kepala } \\
\text { Sekolah dari berbagai jenjang } \\
\text { yang berpeluang untuk } \\
\text { mengikuti Diklat PKS } \\
\text { d. Kebijakan pemerintah yang } \\
\text { mendukung penyelenggaraan } \\
\text { Diklat PKS }\end{array}$ \\
\hline $\begin{array}{l}\text { Harapan/ Aspirations (A) } \\
\text { a.Menjadi lembaga } \\
\text { penyelenggaran Diklat PKS yang } \\
\text { terpercaya } \\
\text { b.Seluruh pengajar Diklat PKS } \\
\text { mempunyai kompetensi yang } \\
\text { cukup sesuai kriteria standar yang } \\
\text { ditetapkan } \\
\text { c.Pembaharuan sistem } \\
\text { pembelajaran Diklat PKS } \\
\text { d.Tersedianya media untuk } \\
\text { menyelesaikan masalah sekolah } \\
\text { secara kolaboratif, reflektif dan } \\
\text { berbasis data yang mampu } \\
\text { menggerakkan ekosistem } \\
\text { pendidikan menjadi lebih berdaya }\end{array}$ & $\begin{array}{l}\text { Menambah volume } \\
\text { penyelenggaraan diklat PKS untuk } \\
\text { menghasilkan lulusan yang lebih } \\
\text { banyak lagi. }\end{array}$ & $\begin{array}{l}\text { Membuat wadah/media dalam } \\
\text { rangka mengoptimalkan dan } \\
\text { memelihara kompetensi lulusan } \\
\text { Diklat PKS sebagai rencana } \\
\text { tindak lanjut pasca diklat PKS. } \\
\text { Mengembangkan kompetensi } \\
\text { para tenaga pengajar Diklat PKS }\end{array}$ \\
\hline $\begin{array}{l}\text { Hasil/Results }(\mathbf{R}) \\
\text { a.Meningkatnya kepercayaan dan } \\
\text { kepuasan stake holder } \\
\text { b.Tercapainya kompetensi kepala } \\
\text { sekolah melalui Diklat PKS } \\
\text { c.Meningkatnya mutu pendidikan } \\
\text { pada semua jenjang di wilayah } \\
\text { DKI Jakarta } \\
\text { d.Terjalinya kerja sama yang baik } \\
\text { dengan semua pihak yang terkait }\end{array}$ & $\begin{array}{l}\text { Memperbaiki pelayanan } \\
\text { penyelenggaraan Diklat PKS } \\
\text { Memenuhi dan mengembangkan } \\
\text { kompetensi para tenaga pengajar } \\
\text { Diklat PKS }\end{array}$ & 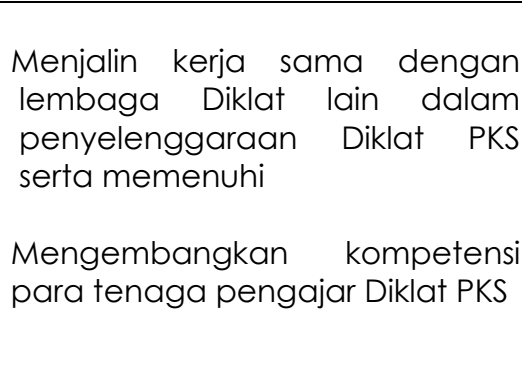 \\
\hline
\end{tabular}

Setelah melakukan kombinasi strategi matriks SOAR selanjutnya membuat analisis model sebagai dasar jumlah skor pada tiap-tiap faktor yang ada pada strategi SR (Kuadran I). Peringkat nilai strategi pada masing-masing d. Strategi OR, merupakan strategi yang berorientasi kepada peluang untuk mencapai hasil yang terukur.
Peluang/Opportunities (O)

Adanya regulasi yang kuat:

Permendiknas no. 32 tahun

2007

3)Permendikbud no. 6 Tahun 2018

4)PP no. 19 tahun 2017

ang kerja sama dengan lain

. Banyaknya jumlah Kepala veklah dariberbagai jenjang yang berpeluang untuk mengikuti Diklat PKS

Kebijakan pemerintah yang mendukung penyelenggaraan Diklat PKS

Membuat wadah/media dalam memelhara kompetensi lulusan Diklat PKS sebagai rencana tindak lanjut pasca diklat PKS.

Mengembangkan kompetensi para tenaga pengajar Diklat PKS kuadran diperoleh dengan menjumlahkan total skor yang dihasilkan pada matriks EFAS, sehingga diperoleh nilai pada masing-masing strategi sebagai berikut:

Total skor strategi SA: 1,35+2,12=3,47 
Total skor strategi OA: $2+2,12=4,12$

Total skor strategi SR: $1,35+1,35=3,7$

Total skor strategi OR: $2+1,35=3,35$.
Berikut disajikan tabel kombinasi strategi berdasarkan penjumlahan skor yang telah dilakukan.

Tabel 7. Matriks Kombinasi Strategi

\begin{tabular}{|l|c|c|}
\hline \multicolumn{1}{|c|}{ IFAS } & Strength (S) & Opportunities (O) \\
\hline Aspirations (A) & Strategi SA & Strategi OA \\
& $\begin{array}{c}\text { Menggunakan kekuatan } \\
\text { untuk memanfaatkan } \\
\text { peluang }=3,47\end{array}$ & $\begin{array}{c}\text { Meminimalkan kelemahan } \\
\text { dengan memanfaatkan } \\
\text { peluang }=4,12\end{array}$ \\
\hline Results (R) & $\begin{array}{c}\text { Strategi SR } \\
\text { Menggunakan kekuatan }\end{array}$ & $\begin{array}{c}\text { Semategi OR } \\
\text { dan menghindari ancaman } \\
\end{array}$ \\
& $\begin{array}{c}\text { untuk mengatasi ancaman }=3,35 \\
3,7\end{array}$ & \\
\hline
\end{tabular}

Tabel 7 menunjukkan 4 kuadran strategi yang dihasilkan berdasarkan perhitungan yang telah dilakukan. Terdapat 4 kuadran strategi yakni Strategi SR (kuadran I), Strategi SA (kuadran II), Strategi OA (kuadran III) dan Strategi OR (kuadran IV). Berdasarkan perolehan nilai pada masing-masing kuadran strategi, strategi OA (kuadran III) merupakan strategi yang memperoleh nilai paling besar yakni 4,12. Hal ini menunjukkan bahwa peluang strategi yang dapat diterapkan pada Diklat PKS yang diselenggarakan oleh BPSDM Provinsi DKI Jakarta adalah strategi OA dengan skor 4,12 diikuti dengan strategi SR pada peringkat kedua dengan skor 3,7. Selanjutnya strategi SA pada peringkat ketiga dengan skor 3,47 dan terakhir adalah strategi OR dengan skor 3,35. Strategi yang mempunyai nilai tertinggi adalah strategi OA, sedangkan strategi yang mempunyai nilai terendah adalah SR. Dengan demikian pada saat ini strategi yang paling tepat diterapkan dalam penyelenggaraan Diklat PKS adalah strategi OA yaitu berorientasi kepada aspirasi/harapan dengan memanfaatkan peluang yang ada yaitu dengan cara melakukan pengembangan Diklat PKS melalui pembuatan wadah/media dalam rangka mengoptimalkan dan memelihara kompetensi Iulusan Diklat PKS sebagai rencana tindak lanjut pasca diklat PKS. Selain itu penting juga untuk melakukan pengembangan kompetensi kepada para tenaga pengajar Diklat PKS. Mengingat saat ini teknologi juga semakin berkembang, sehingga penting untuk membekali para pengajar Diklat PKS baik dalam hal subtatif maupun pendukung khususnya terkait dengan kemajuan teknologi dan tuntutan zaman. Hal ini dikarenakan kemajuan teknologi yang semakin tinggi, sehingga menuntut para Kepala Sekolah untuk menyesuiakan dengan perkembangan teknologi dalam mempimpin satuan pendidikannya sehingga para pengajar Diklat PKS tentunya harus dibekali dengan kompetensi yang lebih dalam rangka mengampu mata pelatihan di Diklat PKS khususnya kompetensi yang terkait dengan teknologi informasi dan komunikasi.

\section{KESIMPULAN \\ Kesimpulan}

Berdasarkan hasil analisis menggunakan Strategi SOAR melalui perhitungan matrik IFAS dan EFAS sehingga didapatkan matriks strategi SOAR, diperoleh hasil bahwa BPSDM Provinsi DKI Jakarta berada pada kuadran III, strategi yang memperoleh nilai tertinggi adalah strategi OA yaitu strategi yang berorientasi pada aspirasi/harapan dengan memanfaatkan peluang yang ada. Pembuatan ruang konsultasi manajerial Kepala Sekolah merupakan salah satu strategi yang tepat untuk diambil pada saat ini dalam rangka meningkatkan mutu Diklat PKS, sehingga para alumni Diklat PKS mempunyai media untuk berkonsultasi khususnya dalam rangka penyusunan dokumen RPS. Media ini menjadi forum bimbingan dan konsultasi bagi para kepala sekolah dalam menjalankan kepemimpinan di masing-masing satuan pendidikan. Selain itu ruang konsultasi manajerial Kepala Sekolah ini juga dapat 
menjadi salah satu bentuk pembinaan kepada para alumni Diklat PKS, sebagai salah satu bentuk layanan pasca diklat.

\section{Rekomendasi}

Dalam rangka mewujudkan ruang konsultasi manajerial Kepala Sekolah, perlu adanya perhatian, dukungan, dan komitmen bersama dari Kepala BPSDM Provinsi DKI Jakarta dan jajarannya bersama widyaiswara untuk mendukung kegiatan perkonsultansian fasilitasi ini dengan sungguh-sungguh. BPSDM Provinsi DKI Jakarta perlu membangun komunikasi dan kerja sama yang baik dengan para kepala sekolah yang nantinya akan menjadi client ruang konsultansi manajerial kepala sekolah.

Ruang konsultasi manajerial kepala Sekolah dapat dibuat secara fisik maupun online/daring. Namun alangkah praktisnya jika pembuatan ruang konsultasi manajerial Kepala Sekolah dibuat secara online/daring dengan menanfaatkan berbagai fasilitas yang ada sehingga para alumni Diklat PKS dapat dengan mudah untuk mengakses ruang perkonsultasian ini dimana saja dan kapan saja tanpa terkendala oleh ruang dan waktu. Hal ini juga didukung oleh situasi saat ini yang masih dalam kondisi new normal, pembuatan ruang konsultasi manajerial kepala sekolah secara online akan sangat efektif dan efisien.

\section{REFERENSI}

Arikunto, Suharsimi, 2010, Prosedur penelitian Suatu Pendekatan Praktek, Jakarta: Rineka Cipta.

Direktur Peningkatan Mutu Pendidik dan Tenaga Kependidikan, 2016, Neraca Pendidikan Daerah Provinsi DKI Jakarta Tahun 2015, Kementerian Pendidikan dan Kebudayaan Republik Indonesia.

Dr. Sopan Adrianto, S.E, M.Pd, M. M., 2020, Efektivitas Model Pembelajaran Koopeatif Tipe STAD Berbasis Keterampilan 4C Pada Diklat Penguatan Kepala Sekolah Angkatan 18 di BPSDM Provisi DKI Jakarta Tahun 2019, Disajikan dalam Orasi Ilmiah Calon Widyaiswara Ahli Utama. Lembaga Administrasi Negara Republik Indonesia, Jakarta, 16 April 2020.

Fuadi, Afnan, Analisis Strategi SOAR Balai Diklat Aparatur Kementerian Kelautan dan
Perikanan Menuju Corporate University, Jurnal Widya Cipta (Online), Volume 4 No.2 edisi 2 September 2020 (https://ejournal.bsi.ac.id dikses 28 januari 2021).

Pemerintah Republik Indonesia, 2013, Peraturan Pemerintah Republik Indonesia Nomor 32 Tahun 2013 tentang Standar Nasional Pendidikan.

Stavros, Jacqueline and Cole Matthew, 2013, SOAR Toward Positive Transformation and Change. Michigan: Lawrence Technologycal University.

Sugiyono, 2010, Metodologi Penelitian, Bandung: Alfabeta.

Suhendra, A. D., Asworowati, R. D., \& Ismawati, T., 2020, Strategi Pengembangan Pemasaran Menggunakan Analisis SOAR dan Matriks QSPM (Studi Kasus: Karamba Jaring Apung Ikan Nila). Akrab Juara, 5(1), 43-54,

(http://www.akrabjuara.com/index.php/a krabjuara/article/view/919, diakses tanggal 10 Februari 2021).

Zamizta, Adelia Alfama, 2020, Analisis SOAR pada Strategi Pemasaran di Industri Jasa Finance, Jurnal Teknik Industri (Online), Volume 6 No.1 Tahun 2020, (https://ejoutnal.uin-suska.ac.id diakses 21 Februari 2021). 